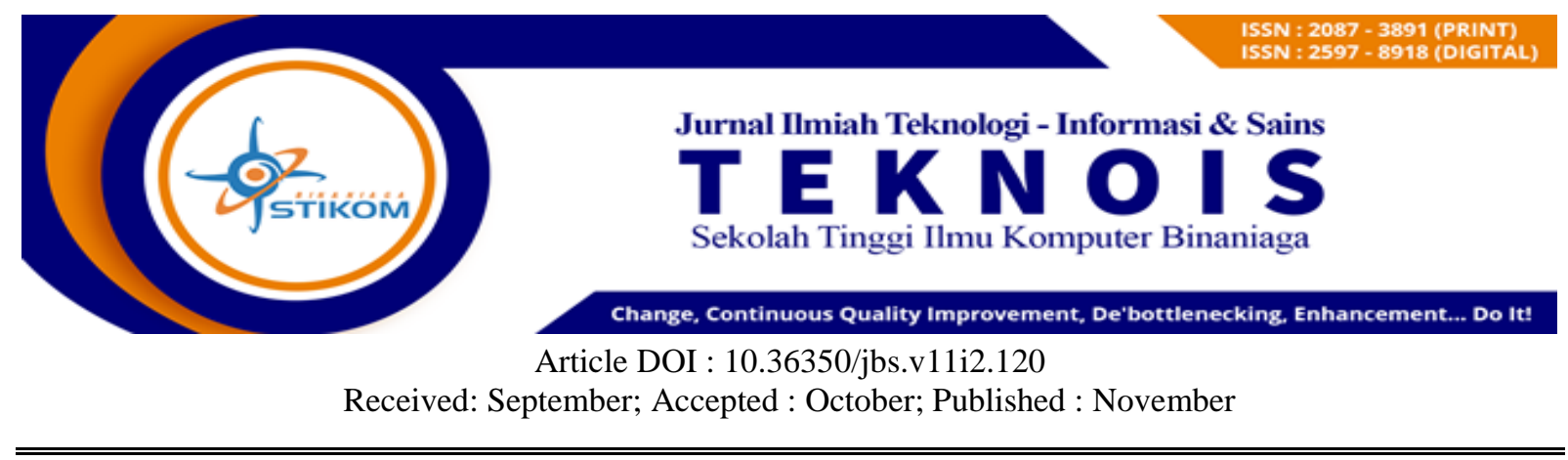

\title{
Penerapan Application Programming Interface (API) Pada Push Notification Untuk Informasi Monitoring Stok Barang Minim
}

\author{
Anggra Triawan $^{1 *}$, Andika Ramot Yesaya Siboro ${ }^{2}$ \\ ${ }^{1}$ Sistem Informasi/Universitas Binaniga Indonesia \\ Email: anggra@unbin.ac.id \\ ${ }^{2}$ Sistem Informasi/ Universitas Binaniga Indonesia \\ Email: andikaramot@gmail.com
}

\begin{abstract}
Technological advances along with the times are getting more targeted and easier in everyday life, one of which is in industrial companies. In every industrial company there is a purchasing department whose job is to make purchases of goods if the stock of goods is running low. But the Purchasing section always has difficulty controlling the minimal stock of goods that are so many in the company, so that there are often delays in purchasing goods, this is due to the ineffectiveness of the process of delivering information about minimal stock data from both the raw material warehouse and from the existing system. In this research, a prototype is made to be a solution to existing problems, where the Application Programming Interface (API) will be able to become a liaison between existing systems and other systems that will send push notifications in sending information about stock data that has reached the limit. minimal when the transaction process is still going on, so as to reduce the level of delay in purchasing goods as a result of the ineffectiveness of notification of information regarding the minimum stock of goods that has occurred so far. A feasibility test has been carried out on the prototype that was built, with a feasibility value of $71 \%$ which means that the prototype built is feasible and has also been tested for accuracy using the Field Observation Method with $80 \%$ effectiveness results.
\end{abstract}

Keywords: Application Programming Interface (API); Push Notification; effectiveness; feasibility; prototype.

\section{ABSTRAK}

Kemajuan teknologi seiring berkembangnya zaman semakin tepat sasaran dan mempermudah dalam kehidupan sehari-hari salah satunya dalam perusahaan industri. Disetiap perusahaan industri terdapat bagian purchasing yang bertugas untuk melakukan pembelian barang jika stok barang sudah menipis. Tetapi bagian Purchasing selalu mengalami kesulitan dalam mengontrol stok barang minim yang begitu banyak pada perusahaan, sehingga kerap terjadi keterlambatan pembelian barang, hal ini disebabkan karena kurang efektifnya proses penyampaian informasi mengenai data stok barang minim baik dari gudang bahan baku maupun dari sistem yang ada. Pada penelitian ini dibuat sebuah prototype untuk menjadi solusi atas permasalahan yang ada, dimana Penerapan Application Programming Interface ( API ) akan mampu menjadi penghubung antara sistem yang sudah ada dengan sistem lain yang akan mengirimkan push notification dalam mengirimkan informasi mengenai data stok barang yang sudah mencapai batas minim ketika masih terjadi proses transaksi, sehingga dapat mengurangi tingkat keterlambatan dalam pembelian barang akibat dari kurang efektifnya pemberitahuan informasi mengenai stok barang minim yang selama ini sudah terjadi. 
Sudah dilakukan uji kelayakan pada prototype yang dibangun, dengan nilai kelayakan sebesar $71 \%$ yang bermakna prototype yang dibangun layak dan juga sudah dilakukan uji akurasi dengan menggunakan Metode Field Observation dengan hasil efektivitas $80 \%$.

Keywords: Application Programming Interface (API); Push Notification; efektivitas; Kelayakan; prototype..

\section{A. PENDAHULUAN}

\section{Latar Belakang}

Dalam suatu perusahaan mengontrol stok barang merupakan hal yang sangat penting karena dengan mengontrol stok barang yang ada akan mempengaruhi baik atau tidaknya proses produksi dari segi ketepatan waktu. Mengontrol stok barang sangat diperlukan pada setiap Perusahaan Industri terutama Perusahan yang bergerak di bidang Produksi yang memerlukan bahan bahan untuk proses produksi (Bahan Baku). Dalam mengontrol stok barang, tiap perusahaan harus selalu update mengenai stok barang minim yang harus segera di pesan atau Buffer Stok.

Dalam mengontrol stok minim inilah yang kerap sekali terjadi keterlambatan dalam melakukan pembelian bahan karena sering terlewatnya data barang yang sudah memasuki batas stok minimum. Sistem yang berjalan pun memiliki kekurangan dimana, untuk setiap barang yang ingin diketahui jumlahnya harus dicari dahulu pada sistem. Dengan kata lain dapat dikatakan sistem yang sudah berjalan saat ini dirasa masih kurang baik dalam struktur pemrogramannya karena tidak dapat nya memberikan informasi mengenai barang dengan stok yang sudah minim secara otomatis.

Dalam ilmu komputer terdapat sebuah teknologi yang dapat menghubungkan 2 aplikasi yaitu API dan juga notifikasi pemberitahuan atau Push Notifikasi. Application Programming Interface (API) merupakan teknologi antarmuka yang dibangun oleh pengembang sistem supaya sebagian atau keseluruhan fungsi sistem dapat diakses secara bersamaan dengan baik. Sementara Representational State Transfer (REST) merupakan salah satu gaya arsitektur dari pengembangan API yang menggunakan Hypertext Transfer Protocol (HTTP) dalam melakukan komunikasi data. Penelitian ini mengimplementasikan gaya arsitektur REST dalam pengembangan API sebagai back-end sistem informasi administrasi pasien klinik perawatan kulit.

API yang dikembangkan menggunakan Javascript Object Notation (JSON) sebagai standar format dalam komunikasi data serta JSON Web Token (JWT) sebagai kode otentikasi pengguna pengguna (Beni Adi Pranata, 2017). Kemudian ada juga teknologi yang digunakan yaitu Push Notification untuk menerima pesan yang dihubungkan oleh API. Push notifications adalah pesan yang muncul pada perangkat pengguna baik dipicu dari secara ance dari aplikasi maupun dorongan (pushed) pesan dari server ke pengguna walaupun aplikasi sedang tidak berjalan ketika terdapat data baru pada server. Teknologi push notification mengijinkan pihak ketiga untuk mengirimkan data secara aktif ke aplikasi yang terdaftar pada server. (Vievin Efendy, Kristian Adi Nugraha, Danny Sebastian, 2019). Dengan adanya layanan Push Notification tersebut, pengguna dapat terbantu dalam hal yang bersipat pemberitahuan secara singkat. Pada implementasinya Push Notification dapat dimanfaatkan dalam berbagai keperluan sehari-hari misalnya untuk monitoring absensi, update berita terbaru, dan sebagainya.

\section{Permasalahan}

Berdasarkan hal tersebut maka identifikasi masalah dalam penelitian ini adalah :

a. Lambatnya menyampaikan respon mengenai informasi ketersediaan barang dari gudang.

b. Belum efektifnya proses pemberitahuan informasi pengecekan pencarian data barang kedalam sistem. 


\section{Tujuan}

Adapun tujuan dari penelitian ini adalah :

a. Untuk medapatkan informasi mengenai stok barang minim secara real time.

b. Mendapatkan proses yang lebih efektif dalam mendapatkan informasi mengenai stok barang minim.

c. Mengembangkan prototype teknologi Application Programming Interface ( API ) untuk akses informasi stok barang minim secara real time.

d. Mengukur tingkat efektifitas penerapan Application Programming Interface ( API ) Pada Push Notification dalam menerima informasi mengenai data stok barang minim.

\section{Tinjauan Pustaka}

Application Programming Interface (API) adalah dasar dari revolusi cloud, seluler, dan Internet Of Thing (IoT). Kecepatan, kemudahan, dan portabilitas data yang dipertukarkan melalui API memungkinkan semua inovasi dan kemudahan modern (Ashby, Jensen, $2018: 5$ ). Dengan demikian dapat di definisikan jenis panggilan atau permintaan yang dapat dibuat, bagaimana membuatnya, format data yang harus digunakan dan konvensi yang harus diikuti. API juga dapat menyediakan mekanisme ekstensi sehingga pengguna dapat memperluas fungsionalitas yang ada dengan berbagai cara dan untuk berbagai tingkat. Secara umum Application Programming Interface (API) merupakan ekspresi terfokus keseluruhan fungsional dalam suatu modul software yang dapat diakses oleh orang yang membutuhkan dengan cara yang telah ditentukan layanan. Representasi terfokus dari fungsi yang dideklarasikan dalam API dimaksudkan untuk menyediakan rangkaian layanan yang spesifik untuk target tertentu. Jika dalam satu modul memiliki API ganda, hal ini sudah menjadi hal yang umum karena setiap API dimaksudkan untuk penggunaan yang spesifik dari modul terkait (Rama dan Avinash, 2015). Jadi API berperan sebagai perantara antar berbagai aplikasi berbeda, baik dalam satu platform yang sama ataupun platform yang berbeda. Pada gambar dibawah ini merupakan Proses Komunikasi yang terjadi pada sistem dengan menggunakan Application Programming Interface.

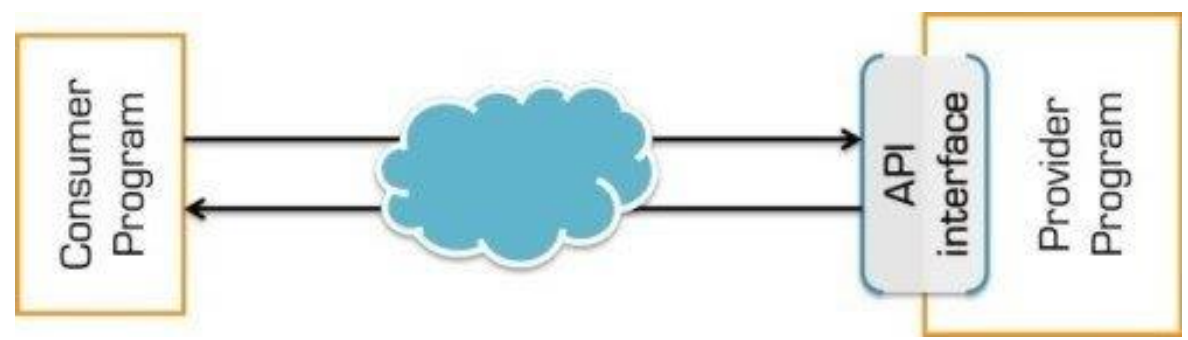

Gambar 1. Proses Komunikasi Sistem Dengan API

Push Notificatin adalah pesan teks singkat yang muncul dilayar perangkat selular. Pengguna dapat menerimanya kapan saja, siang atau malam atau secara realtime. Push notification termasuk ke dalam kategori dari model komunikasi internet, berdasarkan cara mempublikasikan/berlangganannya klien tidak harus menyetujui atau merequest dari server pusat untuk mendapatkan suatu informasi (Manago, 2019 : 17 ). Tidak seperti skenario tradisional (pull) dimana klien harus merequest setiap kali ingin mendapatkan informasi dari sistem. Biasanya push notification akan berbentuk pesan pendek yang muncul pada layar smartphone secara otomatis. Kemudian si pemilik aplikasi akan mengirinkan pesan-pesan setiap saat, walau pemilik smartphone sedang tidak membuka aplikasi tersebut. Bentuk dari push notification ini hampir mirip dengan pesan singkat atau SMS, namun push notification biasanya hanya muncul pada smartphone yang telah menginstall aplikasi bersangkutan. Beberapa pemanfaatan push notification oleh perusahaan antara lain promo produk untuk meningkatkan penjualan, memberikan kenyamanan lebih kepada pelanggan, mengkonversi pengguna aplikasi menjadi menjadi pembeli dan pelanggan, memperlancar proses transaksi, hingga mengarahkan pengguna untuk menggunakan kanal pemasaran tertentu. Kebanyakan push notification akan tampil dalam bentuk pop-up di layar smartphone saat pemilik membuka 
smartphone-nya. Push notification ini akan tetap muncul meskipun app yang mengirimkannya tidak sedang dipergunakan. Berikut ini merupakan skema dari Push Notification.

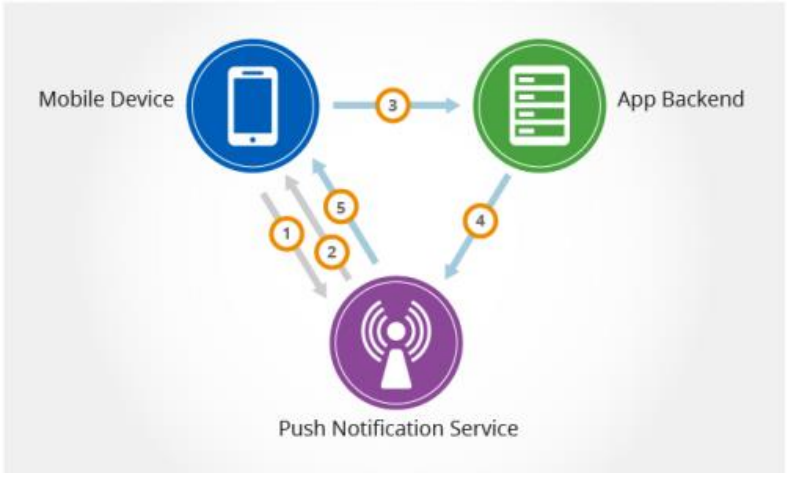

Gambar 2. Skema Push Notification

\section{B. METODE}

\section{Desain Penelitian}

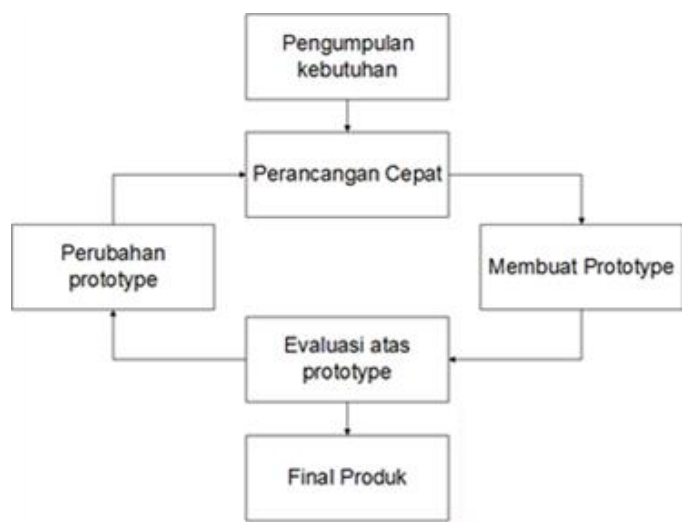

Gambar 3. Prosedur Penelitian

Proses dari prosedur penelitian yang dilakukan sebanyak 7 kegiatan yaitu tahap pertama adalah pengumpulan kebutuhan analisa dimana pelanggan dan pengembang bersama-sama mendefinisikan format seluruh perangkat lunak, menganalisis semua kebutuhan dan garis besar sistem yang akan dibuat. Tahap kedua adalah perancangan cepat dimana perencanaan dilakukan cepat dan rancangan mewakili semua aspek software yang diketahui, dan rancangan ini menjadi dasar pembuatan prototype. Tahap ketiga adalah membuat prototype dimana Membangun design prototyping dengan membuat perancangan sementara yang berfokus pada penyajian kepada pelanggan (misalnya dengan membuat input dan format output). Tahap keempat adalah evaluasi dan prototype dimana evaluasi ini dilakukan oleh pelanggan, apakah prototyping yang sudah dibangun sudah sesuai dengan keinginan pelanggan atau belum. jika sudah sesuai, maka langkah selanjutnya akan diambil. Tahap kelima adalah perubahan prototype dimana prototyping direvisi apabila prototyping belum sesuai maka akan mengulang langkah-langkah sebelumnya. Tahap keenam adalah pengembangan dimana dalam tahap ini prototyping yang sudah di sepakati diterjemahkan ke dalam bahasa pemrograman yang sesuai. Tahap ketujuh adalah Tes Produk dimana setelah sistem sudah menjadi suatu perangkat lunak yang siap pakai, kemudian dilakukan proses pengujian. Pengujian ini dilakukan kepada pengguna

\section{Teknik Analisa Data}

Dalam penelitian ini, metode analisis data dengan menggunakan presentase kelayakan. Adapun rumus yang digunakan adalah sebagai berikut :

$$
\text { Persentase kelayakan }(\%)=\frac{\text { Skor yang diobservasi }}{\text { Skor yang diharapkan }} \times 100 \%
$$

Hasil presentase digunakan untuk memberikan jawaban atas kelayakan dari aspek - aspek yang diteliti. Menurut Arikunto (2009, p.44), pembagian kategori kelayakan ada 5. Skala ini 
Volume 11 Number 2 November 2021 Page. 107-114

Journal Homepage : http://teknois.stikombinaniaga.ac.id/index.php/JBS

DOI Link : http://doi.org/10.36350/jbs.v11i2

memperhatikan rentang dari bilangan presentase. Nilai maksimal yang diharapkan adalah $100 \%$ dan minimum 0\%. Pembagian rentang kategori kelayakan menurut Arikunto (2009, p.44 ) dapat dilihat pada tabel 1

Tabel 1. Tabel Kategori

\begin{tabular}{|c|c|}
\hline Persentase Pencapaian & Interpretasi \\
\hline$<21 \%$ & Sangat Tidak Layak \\
\hline $21 \%-40 \%$ & Tidak Layak \\
\hline $41 \%-60 \%$ & Cukup Layak \\
\hline $61 \%-80 \%$ & Layak \\
\hline $81 \%-100 \%$ & Sangat Layak \\
\hline
\end{tabular}

Untuk mengetahui kelayakan digunakan tabel diatas sebagai acuan penilaian data yang dihasilkan dari validasi pengguna.

\section{HASIL DAN PEMBAHASAN}

\section{Hasil}

Push notifications adalah pesan yang muncul pada perangkat pengguna baik dipicu dari secara langsung dari aplikasi maupun dorongan (pushed) pesan dari server ke pengguna walaupun aplikasi sedang tidak berjalan ketika terdapat data baru pada server. Teknologi push notification mengijinkan pihak ketiga untuk mengirimkan data secara aktif ke aplikasi yang terdaftar pada server. API atau Application Programming Interface adalah sebuah interface yang dapat menghubungkan aplikasi satu dengan aplikasi lainnya. Jadi, API berperan sebagai perantara antar berbagai aplikasi berbeda, baik dalam satu platform yang sama atau lintas platform. Application Programming Interface ( API ) ini yang akan menjadi penghubung untuk dapat mengirimkan notifikasi ke aplikasi lain yaitu Telegram mengenai data stok barang minim.

a. Token dan API Dari Telegram

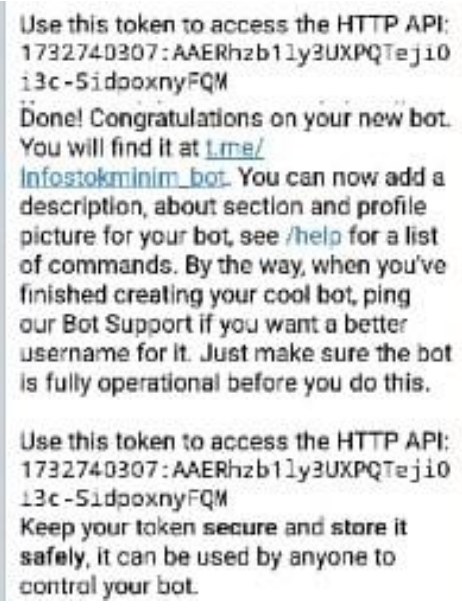

Gambar 4. Token dan BOT Telegram

Pada gambar 4 adalah proses untuk mendapatkain Token API dari Telegram untuk dapat terhubung dengan sistem yang ada pada perusahaan. Cara untuk medapatkan token tersebut adalah dengan mendaftarkan akun Telegram untuk dapat membuat sebuah bot khusus sebagai penerima notifikasi dan pesan masuk dari sistem atau aplikasi lain. Setelah mengikuti langkah - langkah dalam mendaftarkan pembuatan bot Telegram seperti pada gambar 4 maka akan muncul pesan yang dimana dalam pesan tersebut terdapat Token API Telegram yang akan digunakan.

b. Id_chat dari user Telegram sebagai tujuan pengiriman pesan

Pada gambar 5. telah didapatkan id_chat dari user Telegram dari alamat web API Telegram yang akan digunakan dengan cara memasukkan link pada url api.telegram.org/bot1732740307:AAERhzb1ly3UXPQTeji0i3cSidpoxnyFQM/getUpdate. 
Volume 11 Number 2 November 2021 Page. 107-114

Journal Homepage : http://teknois.stikombinaniaga.ac.id/index.php/JBS

DOI Link : http://doi.org/10.36350/jbs.v11i2

Untuk kode yang berada di tengah url tersebut merupakan token dari Telegram yang sudah didapatkan pada langkah di gambar 4 yang berguna sebagai kode untuk dapat mengakses kedalam Telegram setelah melakukan proses input dan memasuki batas stok minim pada sistem yang sudah berjalan. Maka setelah berhasil akan muncul data atau pesan seperti pada gambar 5. yang dimana dalam banyak data tersebut terdapat id_chat dari telegram sebagai penerima pesan dari stok barang minim yang dikirimkan dari sistem yang ada yaitu : 1627832590 .
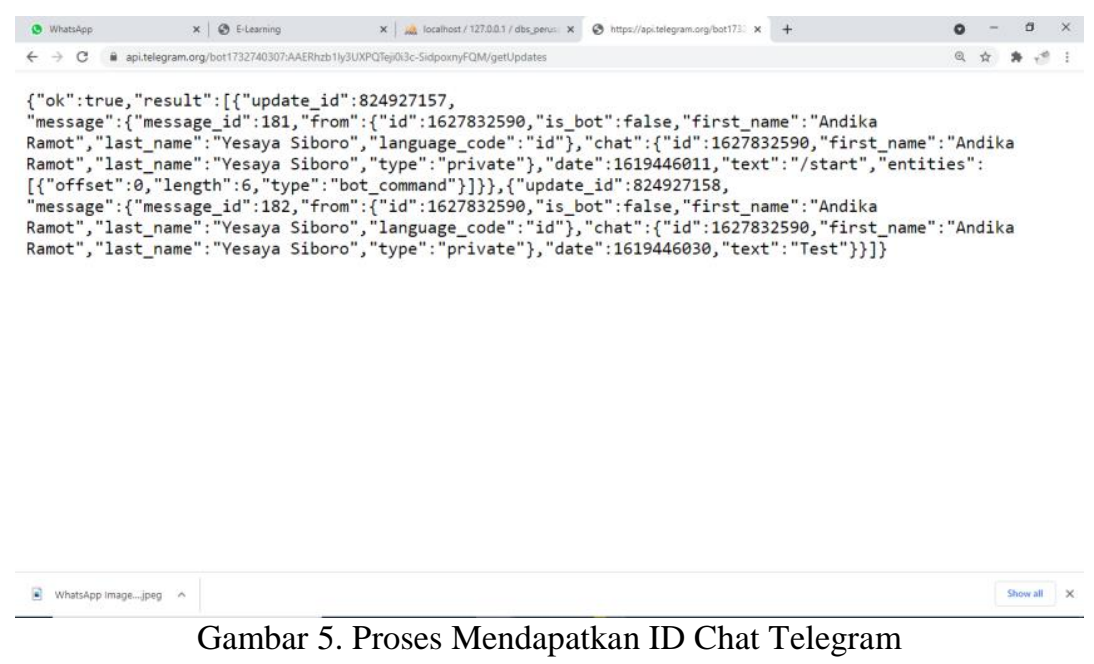

c. Hasil Notifikasi Dari Telegram

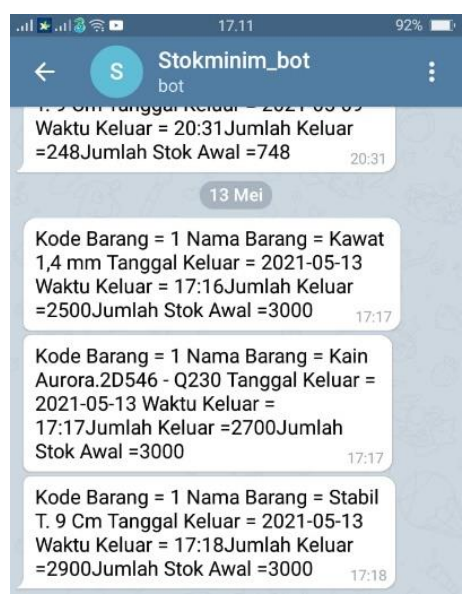

Gambar 6. Hasil Notifikasi Stok Barang Minim

Pada Gambar 6. merupakan notifikasi stok barang minim, pada gambar ini menampilkan data - data barang yang sudah mencapai batas minim untuk segera dipesan kembali. Notifikasi ini akan muncul setelah proses Input Stok Barang Keluar dimana ketika terjadi proses input barang keluar secara terus menerus maka stok barang tersebut akan selalu berkurang, dan ketika stok barang tersebut sudah mencapai batas minim yang ditentukan maka Notifikasi akan muncul pada Telegram dan mengirimkan Informasi mengenai data barang yang telah mencapai batas minim tersebut.

\section{Pembahasan}

Uji produk ini dilakukan untuk mengetahui karakteristik data dari masing - masing variable. Hasil kelayakan yang diteliti dengan hasil kuesioner dibandingkan dengan hasil yang diharapkan. Hasil perhitungan kelayakan dapat dilihat pada tabel 2 berikut.

Tabel 2. Hasil Uji Produk

\begin{tabular}{|c|c|c|c|c|}
\hline \multirow{2}{*}{ Responden } & \multicolumn{4}{|c|}{ Jenis Tanggapan PSSUQ } \\
\cline { 2 - 5 } & Overall & Sysuse & Infoqual & Interqual \\
\hline R1 & 78 & 34 & 28 & 12 \\
\hline
\end{tabular}


Volume 11 Number 2 November 2021 Page. 107-114 Journal Homepage : http://teknois.stikombinaniaga.ac.id/index.php/JBS

DOI Link : http://doi.org/10.36350/jbs.v11i2

\begin{tabular}{|c|c|c|c|c|}
\hline R2 & 80 & 36 & 28 & 12 \\
\hline R3 & 83 & 32 & 35 & 12 \\
\hline R4 & 87 & 36 & 33 & 13 \\
\hline R5 & 91 & 40 & 28 & 13 \\
\hline R6 & 77 & 32 & 29 & 13 \\
\hline R7 & 83 & 36 & $\mathbf{2 1 4}$ & 13 \\
\hline Total Skor & $\mathbf{5 7 9}$ & $\mathbf{2 4 6}$ & $\mathbf{2 4 5}$ & $\mathbf{8 8 5}$ \\
\hline $\begin{array}{c}\text { Total Skor } \\
\text { Yang } \\
\text { Diharapkan }\end{array}$ & $\mathbf{6 6 5}$ & $\mathbf{2 8 0}$ & $\mathbf{8 7 , 3 5 \%}$ & $\mathbf{8 3 , 8 1 \%}$ \\
\hline $\begin{array}{c}\text { Persentase } \\
\text { Kelayakan }\end{array}$ & $\mathbf{8 7 , 0 6 \%}$ & $\mathbf{8 7 , 8 5 \%}$ & & \\
\hline
\end{tabular}

Hasil perhitungan kelayakan diperoleh presentase kelayakan sebesar 87,06\%. Maka dari itu berdasarkan skala likert jika presentase pencapaian 81\%-100\% dikategorikan "Sangat Layak". Kuesioner yang disebarkan disertai pertanyaan pendukung yang meliputi kritik dan saran untuk masukan dari responden. Adapun kritik dan saran yang diberikan oleh pengguna dan ahli yaitu pada saat memprediksi harus menggunakan data terkini. Kritik dan saran tersebut dijadikan bahan evaluasi untuk sistem yang dibuat.

\section{KESIMPULAN}

Berdasarkan hasil penelitian yang telah diselesaikan, dapat ditarik kesimpulan sebagai berikut :

1. Dapat memberikan informasi mengenai stok barang minim kepada bagian pembelian.

2. Informasi data stok barang minim yang diberikan dapat disampaikan secara efektif kepada bagian purchasing tanpa harus bertanya kepada bagian gudang atau menunggu pembertitahuan mengenai informasi stok barang.

3. Dengan menerapkan Application Programming Interface (API) pada prototype mengirimkan push notification untuk monitoring stok barang minim dapat membantu bagian pembelian dalam memonitoring data stok barang yang sudah mencapai batas minim untuk dilakukan pemesanan barang kembali.

4. Telah dilakukan uji kelayakan terhadap prototype yang dikembangkan dengan nilai presentase kelayakan yang didapat berdasarkan kuesioner yang disebarkan pada pengguna sebesar 87.06\% yang berarti prototype yang dikembangkan masuk dalam kategori "Sangat Layak" digunakan. Sedangkan hasil penyebaran pada ahli menunjukan angka kelayakan sebesar $100 \%$. Hal tersebut didasarkan pada tabel kategori kelayakan.

\section{E. DAFTAR PUSTAKA}

[1] Arikunto, S., 2009. Prosedur Penelitian Suatu Pendekatan Praktik. Edisi Revisi 6. Jakarta : Rineka Cipta.

[2] Ashby, Dennis, Claus T. Jensen. 2018. APIs For Dummies A Wiley Brand. John Wiley \& Sons, Inc, United States Of America.

[3] Bin Ladjamudin, Al-Bahra. 2006. Rekayasa Perangkat Lunak. Edisi Pertama, Graha Ilmu, Yogyakarta.

[4] Creswell, John W. 2012. Research Design Pendekatan Kualitatif, Kuantitatif, dan Mixed. Yogyakarta : Pustaka Pelajar.

[5] Distribution, Sap. 2016. Improving And Optimizing Inventory Management. 2617 Sandy Plains, Rd. Marietta, GA 30066.

[6] Efendy, Vievin, dkk. 2019. Implementasi Chat Room Dan Push Notification Pada e-Class Berbasis Mobile. 
Volume 11 Number 2 November 2021 Page. 107-114

Journal Homepage : http://teknois.stikombinaniaga.ac.id/index.php/JBS

DOI Link : http://doi.org/10.36350/ibs.v11i2

[7] F. Widyawati, dkk. 2019. Sistem Informasi Cuti Pegawai Dengan Fitur Push Notifikasi Untuk Badan Kepegawaian Daerah Provinsi.

[8] Ghozaly, Shofiyullah Al. 2019. Implementasi REST API Pada Pusat Informasi Mahasiswa Universitas Teknologi Yogyakarta.

[9] Hasyrif SY, Intan, Indo. 2019. Implementasi RESTFUL API Portal Akademik STMIK Dipanegara Berbasis Android.

[10] Kleppman, Martin dan Alastair R. Beresford. 2017. A Conflict-Free Replicated JSON Datatype. University Of Cambridge Computer Laboratory, Cambridge.

[11] Laila, N. 2011. Sistem Informasi Pengolahan Data Inventory Pada Toko Buku Studi CV. Aneka Ilmu Semarang. Jurnal Teknik Elektro, 3(1), 16. 